\title{
Use of Random Specimens of Urine to Compare Dietary Intakes of African and British Children
}

\author{
E. M. WIDDOWSON and R. A. MCCANCE \\ From Dunn Nutritional Laboratory, Infant Nutrition Research Division, University of Cambridge, \\ and Medical Research Council
}

Widdowson, E. M., and McCance, R. A. (1970). Archives of Disease in Childhood, 45, 547. Use of random specimens of urine to compare the dietary intakes of African and British Children. Specimens of urine were obtained during the forenoon from 45 Ugandan and 45 British boys and girls below 4 years of age who were attending clinics for healthy children.

By employing known facts about the excretion of creatinine, and by making certain assumptions, it was possible to obtain a surprising amount of information about the nature of the food consumed. This agreed well with what was already known about it.

The method has distinct possibilities and could be made more quantitative by using a reference group about which more was known.

It is acknowledged to be next to impossible at present to make any quantitative study of the foods taken in their own homes by children in the developing countries. It is equally difficult to collect 24-hour specimens of urine; yet, if this could be done, the end products of metabolism could at least be compared with those passed by a group of (say) British children - and this could be very informative. The one collection which it is reasonably easy to make is that of the casual (random) sample of urine, and, with the object of trying to find out what can be learned from this, it was decided to use the output of creatinine for getting at the approximate 24-hour excretions of other urinary constituents. This method is described, and some of the results obtained by it in 45 Ugandan and 45 British children of a similar age are presented. Excretions of nitrogen, urea, sodium, potassium, calcium, magnesium, and phosphorus have been estimated, and the total osmolar concentrations of the urine have been measured.

The original object of the study was to find out something about the excretions and, by inference, the intakes of calcium by the African children, and to explore the possibility that there might be some hidden source of the element in the children's environment which enabled them to calcify their bones as satisfactorily as they appeared to do. No hidden source of calcium was in fact discovered and,

Received 27 January 1970. since the excretion of calcium in the urine is not such a good measure of intake as, say, the excretion of potassium is, the method, as applied to calcium, has probably got less quantitative value than it has for some of the other substances which might be investigated.

\section{Material and Methods}

The children in Uganda were attending a clinic at Namulonge, about 15 miles from Kampala. 15 of the children less than 1 year old were entirely breast fed. The other 3 were being given supplementary foods from the M.R.C. Unit. Above the age of about 1 year the only milk most of the African children received, apart from any breast milk the mother may have been able to provide, was a very small amount of cow's milk in the sweet tea which is so popular in the area. This probably did not amount to more than $30-50 \mathrm{ml}$./day, and some children got none at all. 3, however, were being supplied with supplements of dried cow's milk by the M.R.C. Unit. It was estimated by an independent observer that the calcium intakes of a group of such children on their home diets might be of the order of $95 \mathrm{mg}$. calcium/day without supplementary foods and 350 to 500 with supplementary foods supplied by the Unit. The households were living mainly on the staple food of that area, the green plantain banana known as matooke. The toddlers in such households usually get an early morning meal of food left from the night before, sometimes with sweet tea. The midday meal, and usually the evening meal, consist of the staplegenerally matooke steamed without salt or any other 
Composition of Some Ugandan Foods as Prepared by Women in Their own Homes

\begin{tabular}{|c|c|c|c|c|c|c|c|c|c|c|}
\hline Food & $\begin{array}{l}\text { No. of } \\
\text { Samples }\end{array}$ & How Prepared & $\begin{array}{c}\text { Water } \\
(\mathrm{g} \cdot / \\
100 \mathrm{~g} .)\end{array}$ & $\begin{array}{c}\mathbf{N} \\
(\mathrm{g} \cdot / \\
100 \mathrm{~g} .)\end{array}$ & $\begin{array}{c}\mathrm{Ca} \\
(\mathrm{mg} \cdot / \\
100 \mathrm{~g} .)\end{array}$ & $\begin{array}{c}\mathrm{Na} \\
(\mathrm{mg} \cdot ! \\
100 \mathrm{~g} \cdot)\end{array}$ & $\underset{(\mathrm{mg} \cdot /}{\mathrm{K}}$ & $\begin{array}{c}\mathbf{M g} \\
(\mathbf{m g} \cdot / \\
100 \mathbf{g} .)\end{array}$ & $\begin{array}{c}\mathrm{Fe} \\
(\mathrm{mg} / \\
100 \mathrm{~g} .)\end{array}$ & $\begin{array}{c}\mathbf{P} \\
(\mathbf{m g} \cdot / \\
100 \mathrm{~g} .)\end{array}$ \\
\hline $\begin{array}{l}\text { Plantain banana } \\
\text { 'matooke' } \\
\text { Sweet banana } \\
\text { Sweet potato } \\
\text { Cassava } \\
\text { Assorted sauces } \\
>0.9 \% \mathrm{~N} \\
<0.9 \% \mathrm{~N}\end{array}$ & $\begin{array}{l}9 \\
2 \\
4 \\
1 \\
7 \\
7\end{array}$ & $\begin{array}{l}\text { Steamed or boiled } \\
\text { Raw } \\
\text { Steamed or boiled } \\
\text { Steamed } \\
\text { Boiled } \\
\text { Boiled }\end{array}$ & $\begin{array}{l}78 \cdot 0 \\
68 \cdot 0 \\
66 \cdot 0 \\
56 \cdot 4 \\
73 \cdot 9 \\
80 \cdot 8\end{array}$ & $\begin{array}{l}0 \cdot 15 \\
0 \cdot 20 \\
0 \cdot 29 \\
0 \cdot 11 \\
1 \cdot 29 \\
0 \cdot 34\end{array}$ & $\begin{array}{l}0 \cdot 89 \\
1 \cdot 40 \\
6 \cdot 05 \\
5 \cdot 40 \\
17 \cdot 31 \\
17 \cdot 40\end{array}$ & $\begin{array}{c}0 \cdot 99 \\
2 \cdot 35 \\
5 \cdot 38 \\
42 \cdot 0 \\
\\
546 \\
652\end{array}$ & $\begin{array}{l}371 \\
434 \\
418 \\
300 \\
\\
305 \\
233\end{array}$ & $\begin{array}{l}24 \\
45 \\
15 \\
28 \\
\\
27 \\
19\end{array}$ & $\begin{array}{l}0 \cdot 57 \\
0 \cdot 60 \\
1 \cdot 23 \\
1 \cdot 10 \\
2 \cdot 55 \\
2 \cdot 76\end{array}$ & $\begin{array}{r}35 \\
38 \\
42 \\
37 \\
\\
118 \\
58\end{array}$ \\
\hline
\end{tabular}

condiment-but sometimes sweet potato or cassava. The cooked material is kneaded into a stiff paste, and a bolus of this is taken in the fingers, dipped into a sauce made of groundnuts, beans, vegetables, and occasionally meat or fish before being put into the mouth. The mothers do not help their young children to eat their food and, since the coating of the mouthful of matooke with the sauces is a difficult manœuvre for small children, it is always a question how much sauce they get. Some fruit is usually available, often sweet bananas, which the children eat between meals or as they wish. The composition of matooke and some of these foods as eaten are given in Table $I$. The matooke contained much potassium and little sodium, nitrogen, or phosphorus. The sauces were of variable composition, mostly based on groundnuts together with some onions, tomatoes, or green leaves of various kinds. One contained curry powder and the majority were very heavily salted. Some were more dilute than others and they have been arbitrarily divided into two groups according to the amount of nitrogen in them.

Table II shows the minerals found in some well waters used for human consumption near Kampala, and the composition of the Cambridge water is given for comparative purposes. The well waters were collected in the first instance to find out if any of them contained enough calcium to make a sensible contribution to a child's diet. Only an occasional one did so. Most of them, however, contained appreciable amounts of potassium and some of them really large amounts of iron.

The British children had mostly been brought to infant welfare clinics in Cambridge and were all being reared on some form of cow's milk and infant cereals, and other foods as they grew older.

From the results of Daniels and Hejinian (1929), Marples and Levine (1936), and Stearns et al. (1958) it was estimated that the average excretion of creatinine by children less than 1 year old is about $110 \mu \mathrm{M} / \mathrm{kg}$. per $24 \mathrm{hr}$., for children between 1 and 2 years $120 \mu \mathrm{M}$, for those aged 2-3 years $130 \mu \mathrm{M}$, and 3-5 years $140 \mu \mathrm{M}$. The excretion of creatinine by African children living in the Kampala area of Uganda is also of this order (R. G. Whitehead, personal communication 1969). From the concentration of creatinine in the random specimen of urine, a calculation was made of the total volume of urine that would have to be excreted in 24 hours to remove the amount of creatinine/kg. per $24 \mathrm{hr}$., appropriate for the child's age, and this volume was used to calculate the amounts of other urinary constituents likely to have been excreted in 24 hours.

The urines were preserved with a few crystals of thymol. Freezing points were measured with a Fiske Osmometer. Creatinine was determined by the method of Bonsnes and Taussky (1945), urea by the method described by Southgate and Barrett (1966) or by the Biochemical Test Combination Kit, Boehringer Corporation Ltd., and phosphorus by the method of Fiske and Subbarow (1925). An atomic absorption spectrophotometer (SP90 Unicam Instruments Ltd.) was used for the determination of calcium and magnesium, and the same instrument for sodium and potassium which were measured by flame photometry.

\section{TABLE II}

Minerals Found in Waters Taken from Wells near Kampala (mg./l.)

\begin{tabular}{|c|c|c|c|c|c|}
\hline Sample & $\mathrm{Na}$ & $\mathbf{K}$ & $\mathrm{Ca}$ & $\mathbf{M g}$ & $\mathrm{Fe}$ \\
\hline $\begin{array}{r}1 \\
2 \\
3 \\
4 \\
5 \\
6 \\
7 \\
8 \\
9 \\
10 \\
11 \\
12 \\
13 \\
14 \\
15 \\
16 \\
17 \\
18\end{array}$ & $\begin{array}{r}10 \cdot 6 \\
7 \cdot 6 \\
15 \cdot 0 \\
10 \cdot 6 \\
7 \cdot 3 \\
11 \cdot 0 \\
5 \cdot 9 \\
3 \cdot 9 \\
5 \cdot 1 \\
4 \cdot 3 \\
5 \cdot 1 \\
6 \cdot 7 \\
9 \cdot 3 \\
3 \cdot 9 \\
5 \cdot 6 \\
3 \cdot 2 \\
2 \cdot 2 \\
1 \cdot 0\end{array}$ & $\begin{array}{l}2 \cdot 3 \\
3 \cdot 8 \\
4 \cdot 7 \\
3 \cdot 4 \\
1 \cdot 2 \\
1 \cdot 6 \\
2 \cdot 7 \\
2 \cdot 7 \\
0 \cdot 9 \\
4 \cdot 4 \\
5 \cdot 3 \\
8 \cdot 8 \\
4 \cdot 4 \\
1 \cdot 6 \\
4 \cdot 7 \\
3 \cdot 1 \\
2 \cdot 5 \\
1 \cdot 2\end{array}$ & $\begin{array}{r}6 \cdot 1 \\
7 \cdot 5 \\
5 \cdot 5 \\
13 \cdot 8 \\
3 \cdot 4 \\
10 \cdot 2 \\
5 \cdot 4 \\
2 \cdot 2 \\
3 \cdot 0 \\
6 \cdot 0 \\
4 \cdot 4 \\
9 \cdot 0 \\
>16 \cdot 0 \\
2 \cdot 6 \\
3 \cdot 6 \\
1 \cdot 0 \\
1 \cdot 0 \\
3 \cdot 4\end{array}$ & $\begin{array}{l}2 \cdot 2 \\
2 \cdot 4 \\
3 \cdot 2 \\
3 \cdot 8 \\
1 \cdot 2 \\
3 \cdot 9 \\
2 \cdot 4 \\
1 \cdot 4 \\
1 \cdot 7 \\
3 \cdot 8 \\
3 \cdot 3 \\
8 \cdot 4 \\
4 \cdot 8 \\
8 \cdot 5 \\
1 \cdot 8 \\
0 \cdot 6 \\
7 \cdot 5 \\
0 \cdot 4\end{array}$ & $\begin{array}{r}1 \cdot 3 \\
3 \cdot 0 \\
10 \cdot 7 \\
4 \cdot 8 \\
0 \cdot 9 \\
3 \cdot 6 \\
0 \cdot 6 \\
0 \cdot 3 \\
0 \cdot 2 \\
4 \cdot 1 \\
0 \cdot 6 \\
3 \cdot 3 \\
2 \cdot 1 \\
0 \cdot 1 \\
1 \cdot 4 \\
0 \cdot 2 \\
0 \cdot 2 \\
0 \cdot 1\end{array}$ \\
\hline $\begin{array}{l}\text { Mean } \\
\text { SD } \\
\text { Cambridge }\end{array}$ & $\begin{array}{c}6 \cdot 57 \\
3 \cdot 59 \\
11 \cdot 2\end{array}$ & $\begin{array}{l}3 \cdot 29 \\
1 \cdot 93 \\
0 \cdot 03\end{array}$ & $\begin{array}{l}5 \cdot 78 \\
4 \cdot 18 \\
9 \cdot 9\end{array}$ & $\begin{array}{l}3 \cdot 41 \\
2 \cdot 49 \\
0 \cdot 5\end{array}$ & $\begin{array}{l}2 \cdot 08 \\
2 \cdot 64 \\
0 \cdot 02\end{array}$ \\
\hline
\end{tabular}




\section{Results}

Fig. 1 shows the body weights of the children. Even before 1 year of age the weights of the African children began to fall behind. This is a wellrecognized phenomenon in children in the developing countries and has been frequently reported (see McCance, 1970). The children now being described did not in fact fall so badly behind as those in many other communities have been shown to do, and might almost be compared with those studied by Rutishauser (1965) from middle-class children in the same area.

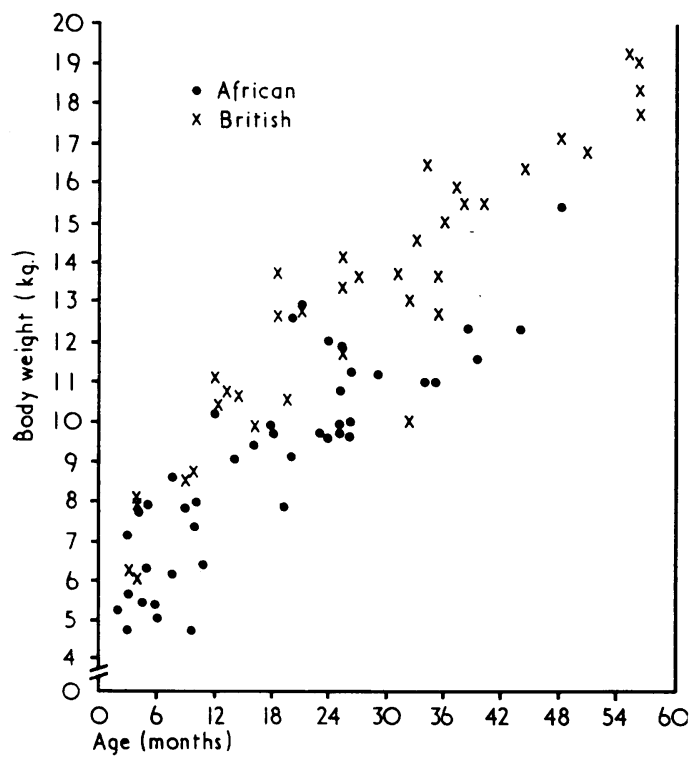

FIG. 1.-Body weights of the children.

Fig. 2 compares the volumes of urine, calculated in the way described, passed by the African and British children $/ \mathrm{kg}$. per $24 \mathrm{hr}$. Only 10 of the African children had urine volumes below $50 \mathrm{ml} . / \mathrm{kg}$., whereas 30 of the British children had volumes in this range. 7 of the African children passed over $150 \mathrm{ml} . / \mathrm{kg}$. per $24 \mathrm{hr}$., whereas none of the British children had volumes as large as this. The mean ml./kg. per $24 \mathrm{hr}$. passed by the African children was $111+85$ and of those passed by the British children $42 \pm 26$; the difference is highly significant $(p<0.001)$.

Fig. 3 shows the same calculated volumes of urine plotted against their osmolar concentrations which are unaffected by any method of calculation. The results for African and British children fall along the same curve and the volumes of the urines, calculated in the way described, are in agreement

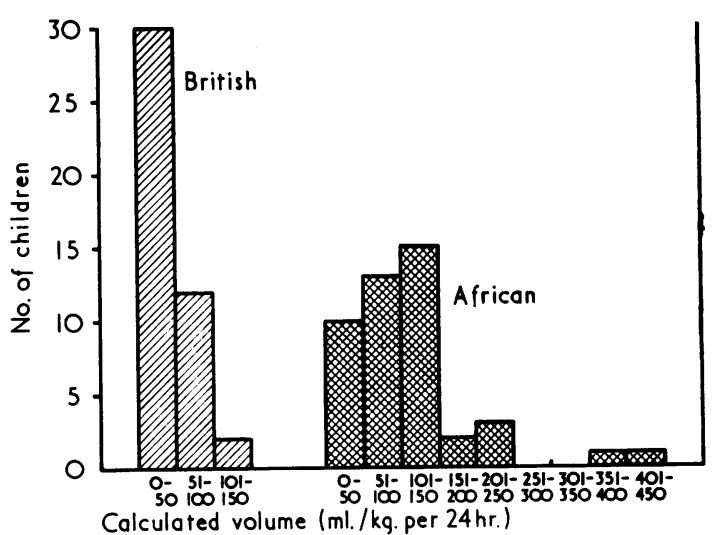

FIG. 2.-Frequency distribution of the urine volumes.

with those to be expected from the osmolar concentrations. The correlation coefficient between log urine volume and osmolar concentration was -0.8141 for the African children, -0.9767 for the Cambridge children, and $-\mathbf{0 . 7 9 9 5}$ for all together. The 4 largest and 4 smallest volumes were omitted for physiological reasons in making this calculation, because the limit to the diluting and concentrating capacity of the children's kidneys appeared to have been reached.

Table III shows the numbers of African and British children in each of the age-groups. 3

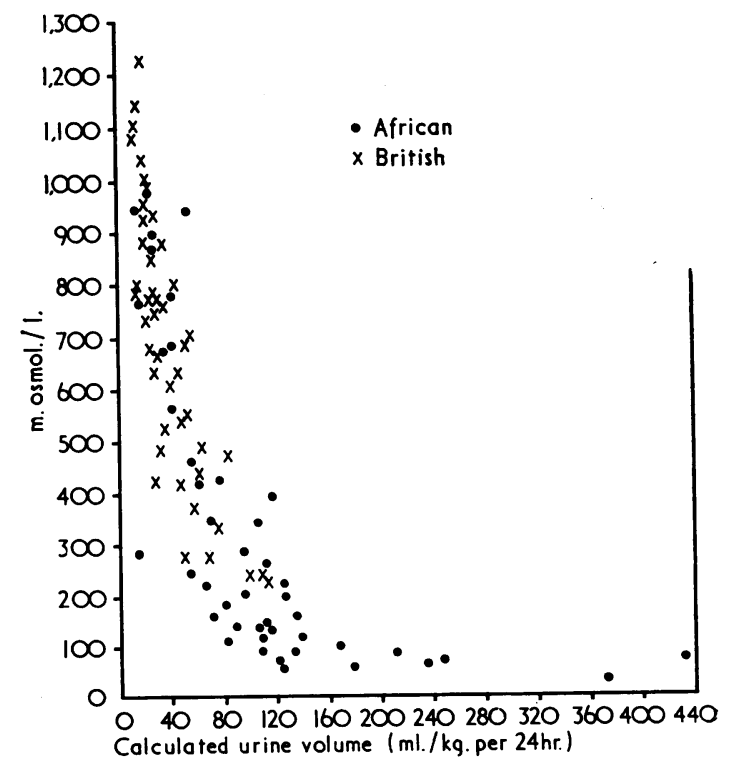

FIG. 3.-Relation between the calculated volumes of urine and their osmolar concentrations. 
TABLE III

Numbers and Age Spread of Children, Means and Ranges of Osmolar Concentrations of Urines, and of Calculated Amounts of Urea, $\mathrm{Na}, \mathrm{K}, \mathrm{Ca}, \mathrm{Mg}$, and P excreted/kg. body weight per $24 \mathrm{hr}$.

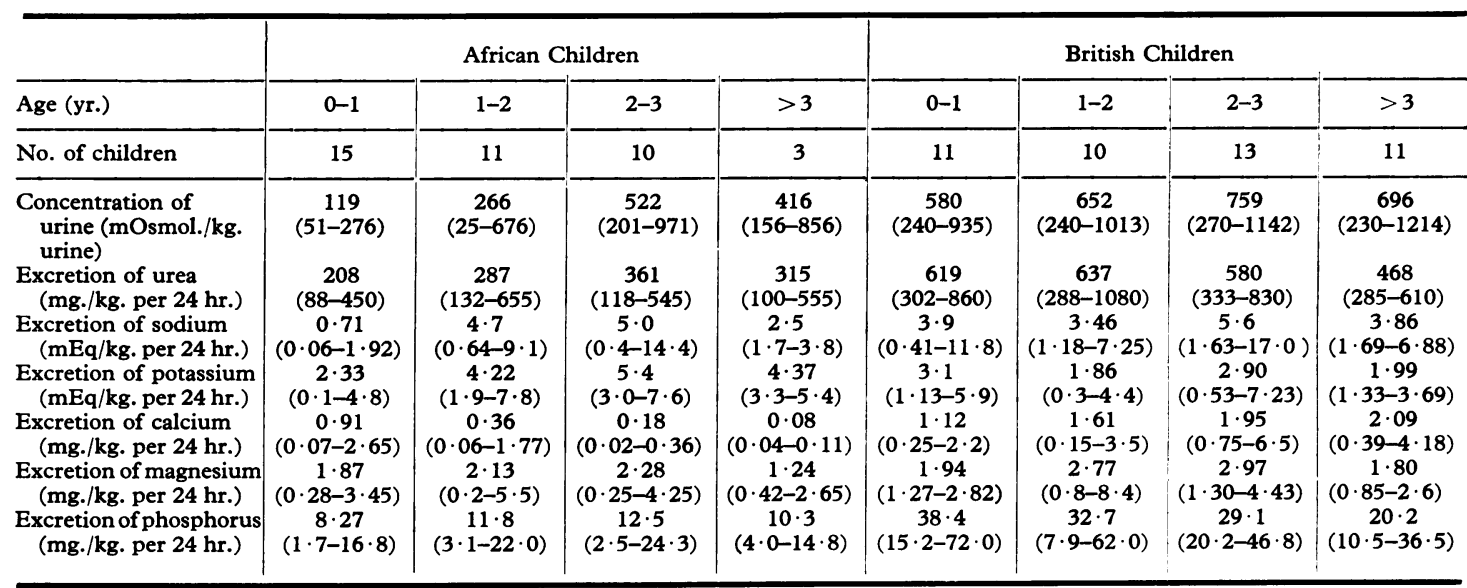

African children between $0-1$ year, 2 between $1-2$ years and 1 more than 3 years, who were receiving supplementary foods from the M.R.C. Unit, have been omitted in constructing this Table. The mean osmolar concentrations of the urines of the African children (also shown in Table III) were lower at all ages than those of the British children and much lower in the two youngest age-groups. The mean concentrations of the urines of the British children are distinctly high by what is reckoned to be normal for young children, and the highest individual concentration, $1214 \mathrm{mOsmol} / \mathrm{kg}$., is remarkable (McCance, Crowne, and Hall, 1969). The African children in all the age-groups excreted less urea $/ \mathrm{kg}$. per $24 \mathrm{hr}$. than the British children did, and the differences were statistically significant ( $p<0.001$ for all age-groups). The means of the calcium excretions of the African and British children were much the same up to the age of 1 year but thereafter those of the African children steadily declined, whereas those of the British went up, and over 3 years of age the African children were only putting out $0.08 \mathrm{mg}$. $/ 24 \mathrm{hr}$. against the $2.09 \mathrm{mg}$. excreted by the British children.

The mean excretion of phosphorus by the African children was much less at each age than that of the British, and ranged from about $22 \%$ to about $50 \%$ of the latter. Both ethnic groups appeared to excrete about the same amount of sodium and magnesium $/ \mathrm{kg}$. per $24 \mathrm{hr}$., but the African children excreted considerably more potassium as judged by the means and ranges in the age-groups over 1 year of age.

\section{Discussion}

The validity of the method we have employed depends upon the assumption that the rate of excretion of creatinine-as of other 'endogenous' substances such as hydroxyproline (Howells, Wharton, and McCance, 1967; Younoszai et al., 1969) - varies little, in most people, throughout the 24 hours, or from one day to another (Folin, 1905; Borst and De Vries, 1950; Stanbury and Thomson, 1951; Thomas, 1959). Within recent years, however, this has been questioned. Brod (1964) suggested that the excretion of creatinine had a circadian rhythm. Edwards, Bayliss, and Millen (1969) claimed that variations from day to day made it useless as an index of the completeness of a 24-hour collection of urine (Folin, 1905). Zorab, Clark, and Harrison (1969) agreed and added, without referring to Brod (1964), that there were considerable variations from time to time within the 24 hours. Chattaway, Hullin, and Odds (1969) found the 24-hour excretion to be correlated with the exchangeable potassium in the muscle mass, to depend to a small extent upon the intake of meat which Folin (1905) had recognized many years before, and, in a few people, to vary with the volume of urine. Variations from person to person were well known to Folin (1905) and those within a 24-hour period must be due to variations in the glomerular filtration rate to which none of the last three papers refer, and about which there is now a vast body of evidence. Such variations in creatinine excretion, however, i.e. those within a period of 24 hours, are certainly small compared with those of the end 
products of the metabolism of substances of 'exogenous' origin or of those with large circadian rhythms. The daily excretion of creatinine may not be constant enough to tell whether all the urine in one of a series of 24-hour collections has been complete (Folin, 1905), but it seems probable that the average results for a group are likely to be quite accurate enough to allow them to be used as an index of the endogenous metabolism of the group, and thus to compare the excretion of substances of exogenous origin by that group with those excreted by another. Since by arrangement, however, all the urines were collected at the same time of day, there may well be an error in the calculated 24-hour excretions of sodium, potassium, and other substances with circadian rhythms, but the error will apply equally to both groups and will not vitiate their comparison.

It appears, indeed, from the present results and considerations, that the method employed is probably quite accurate enough to enable satisfactory comparisons to be made between groups of individuals eating two different diets, and it could be extended in various ways. The excretion of ammonia, titratable acid, amino acids, and other substances might be investigated in this way also, and if the diets of one of the groups were accurately known and had been standardized, the method would have greater potentiality.

High osmolar concentrations in the urine might well have been expected in children living in tropical countries like Uganda and lower ones in children living in temperate climates such as Britain. The reverse was the case, and the findings call for thought. The explanation must lie in the fluid intakes of the African children being much higher than those of the British, and this is in turn probably due to a surprisingly large intake of sweet tea and a diet which contained much more water. In expeditions to a number of villages, one of us (E.M.W.) did her best to find out how much water and tea the young children in 18 families drank in the course of the day. Mothers were questioned through an interpreter and the volumes of the drinking vessels measured. Her conclusions were that the younger children drank an average volume of $560 \mathrm{ml}$. tea and that the range was 240 to 1080 . Even the toddlers had free access to the water pot, so it was not possible to get much idea of their intake of water as such.

The small amount of urea excreted by the African children must mean that they were eating less protein than the British and at the younger ages the figures suggest that they were probably only getting a third to a half as much. If one assumes that the nitrogen excreted as urea accounted for $65 \%$ of the total urinary nitrogen of the African children (Whitehead and Matthew, 1960), and if one adds $20 \%$ of this total to it for nitrogen excreted in the faeces and nitrogen used for growth, one can calculate the protein intake of these African children. If, owing to their much larger intake, one assumes that urea accounted for at least $80 \%$ of the total urinary nitrogen of the British children, and that it would be proper only to add $15 \%$ of this total to it for nitrogen excreted in the faeces (Macy, 1942), and for nitrogen used for growth, one can do the same for the British children. Table IV sets

\section{TABLE IV}

Calculated Intakes of Protein by African and British Children Compared with Amounts Recommended by American (1968) and British (1969) Committees (g./kg. per $24 \mathrm{hr}$. )

\begin{tabular}{l|l|l|l|l}
\hline & $0-1$ & $1-2$ & $2-3$ & $>3$ \\
Age-group (yr.) & $1 \cdot 1$ & $1 \cdot 2$ & $1 \cdot 9$ & $1 \cdot 7$ \\
African children's intakes & $2 \cdot 6$ & $2 \cdot 7$ & $2 \cdot 4$ & $2 \cdot 0$ \\
British children's intakes & $2 \cdot 0$ & $2 \cdot 0$ & $1 \cdot 8$ & $1 \cdot 9$ \\
American recommendations & & & & \\
British recommendations: & $1 \cdot 8$ & $1 \cdot 7$ & $1 \cdot 6$ & $1 \cdot 5$ \\
$\quad$ minimum & $2 \cdot 7$ & $2 \cdot 6$ & $2 \cdot 6$ & $2 \cdot 4$ \\
\hline desirable & & & \\
\hline
\end{tabular}

out the results of these calculations and also the intakes of protein recommended for these ages by the American and British committees in 1968 and 1969 (Food and Nutrition Board, 1968; Department of Health and Social Security, 1969). It is evident that the African children were eating half, or only a little more than half, the amounts of protein covered by the American and 'minimum' British recommendations under the age of 2 , but that thereafter they were getting about the amounts recommended by the American committee and more than the amounts recommended as minimum by the British committee. They were never getting as much as the amounts considered to be realistic and, therefore, desirable by the British committee. The British children in all the agegroups, however, were taking in just about the amounts of protein suggested as desirable by the British committee.

Much more potassium was excreted by the African children than the British children after the age of 1 year, and this can be related to (a) the very large amounts of potassium in matooke, coupled with (b) the large amounts of matooke the children would have to eat to meet their calorie requirements (see above for fluid intakes and osmolar concentrations).

Knapp (1947) found that 10 boys aged 1 year on a 
diet containing $1 \cdot 272$ g. calcium/day excreted a mean amount of $28 \mathrm{mg}$./day. If the children are assumed to have weighed $13.5 \mathrm{~kg}$. their excretion of calcium amounted to about $2 \mathrm{mg}$. $/ \mathrm{kg}$. per $24 \mathrm{hr}$. This is higher than the mean amount excreted by the British children, but the excretion of calcium in the urine is known to vary with the intake, and Knapp's boys were all getting 2 pints of milk a day and further calcium in the rest of their diets. The figures for the British children aged 1 therefore, seem reasonable, and also in agreement with Knapp are the findings that the amounts excreted rose with age. The amounts of calcium excreted by the African children were of the same order as those of the British children till they were 1 year of age, but thereafter the amounts fell, suggesting that the intakes were probably very low and that more and more of the amounts absorbed were being used for growth. Adams and Berridge (1969) stated that the amount of cortical bone in the second metacarpal of normal Ugandan children was small, but they did not state the source of the children with whom the bones were compared. The width of the cortical bone in the African children aged 18 months is certainly less than that of Swiss children if one can compare the midpoint of the shaft (Adams and Berridge, 1969) with the thinnest portion of the shaft (Bonnard, 1968).

The small quantities of phosphorus being excreted by the African children can be explained in terms of their diets. Before 1 year of age the African children were getting mainly breast milk, the British ones cow's milk and cereals, both much richer in phosphorus than breast milk. After 1 year of age the African children were being, or had been, weaned on to matooke and a variable amount of sauces to go with it. The former would have contained very little phosphorus and likewise the sweet potato and cassava. The British children were no doubt being given meat, fish, cow's milk, and cereals, all of which contain much more phosphorus.

The authors are grateful to Ingrid Rutishauser for much help in the early stages and to Carol Boozer and Gillian Foreman for help with the analytical work.

\section{REFERENCES}

Adams, P., and Berridge, F. R. (1969). Effects of kwashiorkor on cortical and trabecular bone. Archives of Disease in Childhood, 44, 705 .

Bonnard, G. D. (1968). Cortical thickness and diaphysial diameter of the metacarpal bones from the age of three months to eleven years. Helvetica Paediatrica Acta, 23, 445.
Bonsnes, R. W., and Taussky, H. H. (1945). On the colorimetric determination of creatinine by the Jaffe reaction. Fournal of Biological Chemistry, 158, 581.

Borst, J. G. G., and De Vries, L. A. (1950). The three types of 'natural' diuresis. Lancet, $2,1$.

Brod, J. (1964). Die Nieren. p. 126. VEB Verlag Volk und Gesundheit, Berlin.

Chattaway, F. W., Hullin, R. P., and Odds, F. C. (1969). The variability of creatinine excretion in normal subjects, mental patients and pregnant women. Clinica Chimica Acta, 26, 567.

Daniels, A. L., and Hejinian, L. M. (1929). Growth in infants from the standpoint of physical measurements and nitrogen metabolism. I. Creatinine. American fournal of Liseases of Children, 37, 1128.

Department of Health and Social Security (1969). Recommended Intakes of Nutrients for the United Kingdom (Reports on Public Health and Medical Subjects, No. 120). H.M.S.O., London.

Edwards, O. M., Bayliss, R. I. S., and Millen, S. (1969). Urinary creatinine excretion as an index of the completeness of 24-hour urine collections. Lancet, 2, 1165.

Fiske, C. H., and Subbarow, Y. (1925). The colorimetric determination of phosphorus. Fournal of Biological Chemistry, 66, 375.

Folin, O. (1905). Laws governing the chemical composition of urine. American fournal of Physiology, 13, 66.

Food and Nutrition Board (1968). Recommended Dietary Allowances: $A$ Report. 7th revised ed. (National Research Council, Publication no. 1694.) National Academy of Sciences: Washington, D.C.

Howells, G. R., Wharton, B. A., and McCance, R. A. (1967). Value of hydroxyproline indices in malnutrition. Lancet, 1 , 1082.

Knapp, E. L. (1947). Factors influencing the urinary excretion of calcium. I. In normal persons. Fournal of Clinical Investigation, 26, 182.

McCance, R. A. (1970). Malnutrition in the children of underdeveloped countries. In Recent Advances in Paediatrics, 4th ed. Ed. by D. Gairdner and D. Hull. Churchill, London.

-, Crowne, R. S., and Hall, T. S. (1969). The effect of malnutrition and food habits on the concentrating power of the kidney. Clinical Science, 37, 471.

Macy, I. G. (1942). Nutrition and Chemical Growth in Childhood, Vol. 1, Evaluation. Charles C. Thomas, Springfield, Illinois.

Marples, E., and Levine, S. Z. (1936). Creatinuria of infancy and childhood. 1. Normal variations: creatine tolerance tests and he effect of aminoacetic acid in normal infants. American fournal of Diseases of Children, 51, 30.

Rutishauser, I. H. E. (1965). Heights and weights of middle class Baganda children. Lancet, 2, 565.

Southgate, D. A. T., and Barrett, I. M. (1966). The intake and excretion of calorific constituents by babies. British fournal of Nutrition, 20, 363.

Stanbury, S. W., and Thomson, A. E. (1951). Diurnal variations in electrolyte excretion. Clinical Science, 10, 267.

Stearns, G., Newman, K. J., McKinley, J. B., and Jeans. P. C. (1958). The protein requirements of children from one to ten years of age. Annals of the New York Academy of Sciences, 69, 857.

Thomas, S. (1959). Effects of change of posture on the diurnal renal excretory rhythm. Fournal of Physiology, 148, 489.

Whitehead, R. G., and Matthew, C. E. (1960). The analysis of urine of children suffering from kwashiorkor. East African Medical fournal, 37, 384.

Younoszai, M. K., Kacic, A., Dilling, L., and Haworth, J. C. (1969). Urinary hydroxyproline: creatinine ratio in normal term, pre-term, and growth-retarded infants. Archives of Disease in Childhood, 44, 517.

Zorab, P. A., Clark, S., and Harrison, A. (1969). Creatinine excretion. Lancet, $2,1254$.

Correspondence to Dr. E. M. Widdowson, Dunn Nutritional Laboratory, Milton Road, Cambridge. 